\title{
ХАРАКТЕРИСТИКА АДМІНІСТРАТИВНИХ ФОРМ ТА МЕТОДІВ ЗДІЙСНЕННЯ ВІДОМЧОГО КОНТРОЛЮ ЗА ДІЯЛЬНІСТЮ СУДІВ (СУДДІВ) В УКРАїНІ
}

\author{
ВАСИЛЕНКО Ярослав Миколайович - здобувач Інституту права та \\ суспільних відносин Відкритого міжнародного університету розвитку людини \\ «Україна»
}

DOI:10.32782/EP.2020.1.6

УДК 342.9 (477)

\begin{abstract}
У статті, спираючись на аналіз норм чинного законодавства та наукових поглядів учених, визначено та охарактеризовано адміністративні борми та методи здійснення відомчого контролю за діяльністю судів (суддів) в Украӥні. Констатовано, щзо визначення та дослідження адміністративних борм та методів здійснення відомчого контролю за діяльністю судів (суддів) в Україні має важливе теоретичне та практичне значення, оскільки саме иі наукові категорій найбільш повно та всебічно відображають сутність та призначення такої контрольної діяльності.
\end{abstract}

Під адміністративно-правовими формами здійснення відомчого контролю за діяльністю судів (суддів) в Украӥні розуміється зовнішній вираз практичной діяльності уповноважених суб'єктів, яка пов'язана із реалізацією ними своӥх контрольних повноважень та спрямована на досягнення кінщевої мети, яка полягає у забезпеченні здійснення якісного, ефбективного та законного судочинства в нашій державі. До таких форм віднесено: безпосередню перевірку діяльності суддів, різновидами якої $є$ : інспектування, огляд, ревізія, інвентаризачія; а також ознайомлення зі статистичною звітністю, яка надходить від підконтрольного суб'єкта.

Адміністративно-правові методи здійснення контролю за діяльністю судів (суддів) в Україні запропоновано розуміти як сукупність законодавчо визначених інструментів прийомів та засобів, які у свойй діяльності використовують уповноважені суб'єкти при здійсненні контрольної діяльності в досліджу- ваній сбері суспільних відносин. До вказаних методів віднесено: метод переконання; розпорядчий метод; метод дисииплінарного впливу; метод планування; метод регламентування.

Ключові слова: адміністративний метод, адміністративна форма, відомчий контроль.

Постановка проблеми

На сьогодні відбувається активне реформування фактично всіх сфер суспільного життя і діяльність суддів у цьому контексті не стала винятком. Зокрема, на нашу думку, особливо гостро стоїть питання покращення ефективності відомчого контролю за діяльністю суддів. Здійснення відомчого контролю за діяльністю судів (суддів) є складним та багатоаспектним явищем, реалізація якого має здійснюватись у певних формах та за допомогою використання специфічних методів, дослідженню яких і буде присвячено наукове дослідження. Важливість розгляду форм і методів відомчого контролю обумовлюється тим, що саме дані категорії найбільш змістовно відображають практичний бік здійснення відомчого контролю.

\section{Стан дослідження}

Проблема забезпечення законності судочинства неодноразово потрапляла у поле зору різних науковців. Зокрема, ій приділяли увагу О.С. Захарова, В.С. Ковальський, В.С. Аукомський, В.С. Бігун, О.Ф. Скакун, Н.Ю. Задирака, Ю.І. Римаренко, Я.Ю. Кондратьєв, А.В. Малько, О.М. Музичук, А.Ф. Крижановський, В.В. Комаров, 


\section{Адміністративне право}

О.ภ. Копиленко, Н.М. Оніщенко, О.В. Зайчук та багато інших. Разом із тим, незважаючи на чималу кількість наукових розробок, у юридичній літературі відсутні комплексні дослідження, присвячені відомчому контролю за діяльністю судів (суддів) в Україні, а питання форм і методів такого контролю не розглядалось взагалі.

Саме тому метою статті є: визначити та охарактеризувати адміністративні форми та методи здійснення відомчого контролю за діяльністю судів (суддів) в Україні.

\section{Виклад основного матеріалу}

Починаючи наукове дослідження, слід відзначити, що під адміністративно-правовими формами здійснення відомчого контролю за діяльністю судів (суддів) в Україні слід розуміти зовнішній вираз практичної діяльності уповноважених суб'єктів, яка пов'язана із реалізацією ними своїх контрольних повноважень та спрямована на досягнення кінцевої мети яка полягає у забезпеченні здійснення якісного, ефективного та законного судочинства в нашій державі. До відповідних форм, на нашу думку, слід віднести такі, як:

- ревізія. Це форма документального контролю за фінансово-господарською діяльністю судів, дотриманням законодавства 3 фінансових питань; спосіб документального викриття недостач, розтрат, привласнень та крадіжок коштів і матеріальних цінностей, попередження фінансових зловживань. Основна мета ревізії - виявити господарські і фінансові порушення, зловживання, факти безгосподарності, розкрадання, марнотратства, установити причини та умови, які їм сприяли, і винних у цьому осіб, ужити заходів до відшкодування завданого збитку, шкоди, розробити заходи по усуненню недоліків і порушень, а також притягнути до відповідальності (адміністративної чи кримінальної) осіб, які допустили правопорушення [1]. Так, у структурі апарату суду маються відділи аудиту, ревізії та планово-фінансової діяльності, серед завдань яких є аудит обліку матеріальних запасів і малоцінних та швидкозношуваних предметів; контроль за ефективним і ці- льовим використанням бюджетних коштів суду; контроль за наявністю і рухом майна, використанням фінансових і матеріальних (нематеріальних) ресурсів суду; - аудит обліку поштових марок та паперу, відповідно до плану роботи або за дорученням керівництва суду проведення аналізу стану роботи відповідних структурних підрозділів, аналіз причин, що впливають на погіршення цієї роботи, ініціювання заходів щодо запобігання ним та ін. [2];

- інвентаризація. Дослідники сфери контролю в органах внутрішніх справ зазначають, що інвентаризація - це переоблік матеріальних цінностей, закріплених за відповідним органом, у кількісному та номенклатурному вираженні за станом на певне число (за планом) або у зв'язку з прийомомздачею матеріальних цінностей при заміні матеріально відповідальних осіб [3, с.519]. Сьомий апеляційний адміністративний суд пояснив необхідність проведення інвентаризації в установах судової системи та проблеми, які виникають під час ії проведення. Так, найпоширенішими помилками під час проведення річної інвентаризації $\epsilon$ такі: ненадання керівнику установи матеріалів інвентаризації щодо придатності для використання об'єктів основних засобів, залишкова вартість яких дорівнює нулю, для прийняття необхідних управлінських рішень щодо подальшої її експлуатації або списання, що призводить до відображення недостовірної інформації про необоротні активи у фінансовій звітності; непроведення перевірки правильності присвоєння інвентаризаційних номерів; включення до складу інвентаризаційної комісії матеріально відповідальної особи, що створює ризики недостовірності даних інвентаризації; непроведення інвентаризації незавершених капітальних інвестицій та інвентаризації активів та зобов'язань, які обліковуються на позабалансових рахунках, а саме особистого майна працівників суду, що використовуються ними в роботі відповідно до заяв; непроведення інвентаризації дебіторської та кредиторської заборгованості за розрахунками 3 постачальниками товарів, робіт та послуг [4]; 
- ознайомлення зі статистичною звітністю, яка надходить від підконтрольного об'єкта (зокрема суду). Статистичний контроль дає уявлення про кількісні характеристики суспільних явищ. У процесі організації статистичного контролю збираються та обробляються дані про стан роботи конкретного суду. Без статистичних даних та їх наукової обробки неможливо мати достовірну інформацію про стан як керованої, так і управляючої систем, а отже, й організувати ефективне управління. Статистичний контроль має свої конкретні форми виявлення: звіт, вибіркове дослідження та ін. [5];

- оцінювання. Оцінювання якості діяльності суду дає можливість вирішувати такі завдання: отримання інформації про поточну ситуацію; обгрунтування поточних та стратегічних рішень; визначення пріоритетів для змін; моніторинг інновацій, оцінка їхньої результативності та ефективності; оцінювання відповідності роботи суду існуючим стандартам та нормативам [6]. Міжнародний досвід оцінювання якості роботи суду дає підстави визначити основні складові елементи цього процесу: стандарти якості роботи суду - кількісні та якісні характеристики роботи суду як спеціалізованої державної установи, які формуються відповідно до базових цінностей судової системи та демократичного суспільства і можуть бути зафіксовані у вигляді процесуальних вимог, нормативів, суспільних очікувань тощо; критерії якості роботи суду - суттєві відмінні ознаки якості роботи суду, що є базисом процедур оцінки якості, зокрема вибору показників та методів оцінювання; показники якості роботи суду - кількісні чи якісні дані, які визначають рівень відповідності роботи суду сформульованим критеріям якості; методи оцінювання - сукупність стандартних засобів дослідження та прийомів отримання, обробки та аналізу даних про діяльність суду: збір та аналіз статистичної інформації, огляд та аналіз документів, опитування тощо [6];

- моніторинг (спостереження, аналіз). На сьогодні Европейська комісія 3 питань ефективності правосуддя (СКЕП) приділяє значну увагу моніторингу та оцінюванню діяльності судів у країнах - членах Ради Европи.
У своїх документах ЕКЕП зазначає, що «моніторинг та оцінювання набувають дедалі більшого значення як інструмент, який дає змогу проводити вимірювання ситуацій, визначати результати реалізації політики та асигнувати ресурси, яких стає дедалі менше» Крім того, на думку ЕКЕП, «системи моніторингу та оцінювання повинні сприяти підвищенню дієвості правосуддя та якості роботи судів, а отже, забезпечувати більш узгоджену реалізацію завдань» [6]. Періодична оцінка та моніторинг якості правосуддя і функціонування судів рекомендується як частина процесу управління судами». Крім того, СКЕП вважає, що «інформація стосовно рівня задоволеності громадян - користувачів судів та працівників судів (суддів i працівників апарату суду) роботою суду, а також щодо рівня їхньої довіри до суду 6 доцільними інструментом для формування політики стосовно підвищення якості функціонування судової системи» [6];

- перевірка стану виконання управлінських рішень. М.С. Орлів зазначає, що управлінське рішення - це результат вибору суб'єктом управління найкращої альтернативи, спрямованої на розв'язання певної управлінської проблеми. Основна мета управлінського рішення, на думку автора, полягає у тому, що забезпечити координуючий вплив на об'єкт управління для досягнення цілей організації [7, с.3]. Мета контролю за виконанням управлінських рішень полягає в одержанні повідомлень про режим функціонування системи управління, про ефективність зусиль, які здійснюються виконавцями, і дозволяє намітити заходи, що складають зміст наступної стадії цього етапу - коригування управлінського рішення та регулювання системи управління. Ознайомлення 3 діяльністю працівників підконтрольних органів відбувається також під час проведення різних нарад, активів, інструктажів, зібрань, злетів і т. ін., цінність яких багато в чому визначається рівнем критики та самокритики [3, с. 519].

Отже, основними формами безпосередньої перевірки діяльності судів є: інспектування, огляд, ревізія, інвентаризація; ознайомлення зі статистичною звітністю, яка надходить із підконтрольного суб'єкта; 


\section{Адміністративне право}

оцінювання; перевірка стану виконання управлінських рішень. Варто відзначити, що форми нерозривно пов'язані із методами здійснення відповідної діяльності. Адже саме останні вказують на те, за допомогою яких саме інструментів та засобів така діяльність реалізовується. У свою чергу, під адміністративно-правовими методами здійснення контролю за діяльністю судів (суддів) в Україні слід розуміти сукупність законодавчо визначених інструментів прийомів та засобів, які у своїй діяльності використовують уповноважені суб'єкти при здійсненні контрольної діяльності в досліджуваній сфері суспільних відносин. Спираючись на аналіз наукових поглядів учених та норм чинного законодавства, ми виокремили наступні методі здійснення відповідної діяльності:

- метод переконання. Переконання як адміністративно-правовий метод виявляється у психолого-педагогічному впливові на волю і почуття суб'єктів, підпорядковуючи тим самим свідомі вчинки правовому контролю. Переконання - це спосіб формування у відповідних осіб певної свідомості, звички добровільного виконання встановленої поведінки. Іншими словами, спосіб впливу зазначеного методу будується так, що особа не зобов'язується, а закликається до досягнення корисного для суспільства і держави результату. Зазначена специфічна особливість дає змогу нам виділити розглянутий метод регулювання в самостійний особливий регулятор суспільних відносин [8, с. 40]. В «арсеналі» методу переконання перебувають такі способи стимулювання, як заохочення, рекомендації, роз'яснення, виховання, договори тощо. Деякі автори справедливо відзначають зміщення центру ваги від прямого юридично владного впливу до методів погоджень і надання допомоги. Однак сьогодні, зазначає В. Мурза, органи контролю й нагляду недостатньо ефективно оперують цими способами впливу на підконтрольні об'єкти. Звітність контрольних і наглядових органів констатуе різні відхилення, аномалії, порушення норм; містить факти про притягнення винних до відповідальності [9, с. 113]. На нашу думку, використання методу переконання має одне із пріоритетних значень у контексті здійснен- ня відомчого контролю за діяльністю судів (суддів), що пояснюється особливим адміністративно-правовим статусом останніх;

- розпорядчий метод. Цей метод використовується як в управлінні так і в контролі та розуміється як сукупність способів i засобів впливу на персонал, що базуються на владі та дисципліні. Головна особливість - прямий вплив на об'єкт і поведінку виконавців у певній обстановці. Формою вираження є розпорядження і накази вищого органу, які носять обов'язковий характер для нижчестоящого. Засновані на чіткому розмежуванні прав, відповідальності та обов' язків керуючого органу, які закріплені в положеннях структурних підрозділів, інструкціях і функціональних обов'язках посадових осіб [10, с. 111]. Розпорядчі методи відображають поточне використання встановлених організаційних зв'язків, їх часткове коригування в разі зміни умов роботи. В основі розпорядчого впливу методів цієї групи лежать повноваження органів виконавчої влади - закріплені в установленому порядку права і обов'язки цих органів [11, c. 20];

- метод дисциплінарного пливу. У трудових колективах повинна створюватись обстановка нетерпимості до порушень трудової дисципліни, суворої вимогливості до працівників, які несумлінно виконують трудові обов'язки. Щодо окремих несумлінних працівників застосовуються в необхідних випадках заходи дисциплінарного впливу [12]. Як уже відзначалось раніше, судді за невиконання або неналежне виконання своїх обов'язків можуть бути притягнені до певного виду відповідальності, підстави настання якої чітко визначені на законодавчому рівні. Варто відмітити, що дисциплінарний вплив у якості дисциплінарних стягнень (ДС) має такі правила накладення: вид ДС повинен відповідати чинному законодавству; особа, орган, який накладає стягнення, повинен мати відповідні повноваження; він може діяти тільки в межах своєї компетенції; ДС накладає безпосередній керівник; ДС повинне бути організаційно оформлене; за одне порушення дисципліни може бути накладено тільки одне адміністративне дисциплінарне стягнення (воно 
може бути поєднане з економічними санкціями, що застосовуються всередині підприємства); ДС можуть накладатися тільки за реальні порушення [13];

- метод планування. Планування - це стержнева частина всіх систем управління, процес, за допомогою якого система пристосовує свої ресурси до змін зовнішніх і внутрішніх умов. Планування $є$ найпершою функцією управління, яка передує всім іншим, визначаючи їх природу. Планування залежить від ефективного аналізу зовнішнього середовища, об'єктивної оцінки власних ресурсів, вимагає спільних зусиль і участі всіх складових частин організації [14, c.170]. Варто навести думку В.Г. Воронкової, яка відзначає, що методи планування як складова частина методології планування - це сукупність способів і прийомів, за допомогою яких забезпечується розробка і обгрунтування планових документів. Вони покликані виробити систему різноманітних засобів і прийомів вивчення й узагальнення процесів функціонування різних соціальноекономічних об'єктів, а також спосіб здійснення процесу планування, тобто спосіб реалізації планової ідеї. Будь-який метод планування залежить від конкретної форми планування і включає: напрямок планування; засоби обгрунтування планових параметрів [15]. Таким чином, застосування методу планування має важливе значення з точки зору забезпечення якісного, послідовного та результативного здійснення відомчого контролю. Саме належним чином побудований заздалегідь план дозволяє у майбутньому правильно розподілити фінансові, матеріальні, технічні та людські ресурси;

- метод регламентування. Загальноорганізаційні методи регламентування діяльності функціонують за допомогою дії законів, які на загальноорганізаційному рівні визначають правове регулювання питань відповідної діяльності, у тому числі і виконання повноважень у судових органах. Як підкреслюють М.Г. Матузов та О.В. Малько, механізм правового регулювання є системою юридичних засобів, організованих у найбільш послідовному порядку з метою впорядкування суспільних відносин, сприяння задоволенню інтересів суб’єктів права.
Маючи певну структурну єдність та логічну послідовність, ця система засобів здійснює регламентацію суспільних відносин, сприяє задоволенню інтересів і потреб суб’єктів [16, c.552].

\section{Висновок}

Таким чином, завершуючи представлене дослідження, слід констатувати, що визначення та дослідження адміністративних форм та методів здійснення відомчого контролю за діяльністю судів (суддів) в Україні має важливе теоретичне та практичне значення, оскільки саме ці наукові категорії найбільш повно та всебічно відображають сутність та призначення такої контрольної діяльності. Так, якщо форми вказують на те, яким саме чином здійснюється відомчий контроль (є його зовнішнім відображенням), то методи вказують на те, за рахунок чого, тобто використання яких засобів та інструментів, було досягнуто кінцевої мети контролю.

\section{Аітература}

1. Гуцаленко А. В., Дерій В. А., Коцупатрий М. М. Державний фінансовий контроль:навч. посіб. [для студ. вищ. навч. закл.]/ К.: Центр учбової літератури, 2009. 424 с. URL: https://pidruchniki. com/1584072029893/finansi/derzhavniy_ finansoviy_kontrol

2. Сьомий Апеляційний адміністративний суд. Апарат суду. URL: https://7aac. gov.ua/pro-sud/struktura-sudu/aparat-sudu/ viddil-auditu-revizi\% D $1 \% 97$-ta-planovofinansovo\%D1\%97-diyalnosti/viddil-auditurevizi\%D1\%97-ta-planovo-finansovo\%D1\%97diyalnosti/

3. Плішкін В.М. Теорія управління органами внутрішніх справ: Підручник / За ред. канд. юрид. наук Ю.Ф. Кравченка. Київ. Національна академія внутрішніх справ України, 1999. 702 с.

4. Необхідність проведення інвентаризації в установах судової системи та проблеми, які виникають під час ії проведення. Сьомий Апеляційний адміністративний суд. Апарат суду. URL: https://7aac.gov.ua/neobxidnist-provedennyainventarizaci \% D $1 \% 97$-v-ustanovax- 


\section{Адміністративне право}

sudovo\%D1\%97-sistemi-ta-problemi-yakivinikayut-pid-chas-\%D $1 \% 97 \%$ D $1 \% 97$ provedennya/

5. Ромасько В.О. Державний контроль у сфері будівництва: адміністративно-правові засади: дис. ... канд. юрид. наук : 12.00 .07 / B.О. Ромасько ; Харк. нац. ун-т внутр. справ. X., 2010. $18 \mathrm{c}$.

6. Система оцінювання роботи суду: стандарти, критерії, показники та методи / [Електронний ресурс] Режим доступу: https://court.gov.ua/userfiles/sors 15.pdf

7. Орлів М. С. Підготовка і прийняття управлінських рішень : навч.-метод. матеріали / М. С. Орлів ; упоряд. Г. І. Бондаренко. К. : НАДУ, 2013. 40 с

8. Чуприна Ю. Ю. Адміністративноправові методи правового регулювання: сутність та зміст [Текст] : автореф. дис. ... канд. юрид. наук: 12.00.07; Харків. нац. ун-т ім. В. Н. Каразіна. Харків. 2017. 21 с.

9. Мазур В. Форми та методи державної контрольно-наглядової діяльності.Публічне право. 2013. № 2 (10). С. 110-116.

10. Рудінська О. В., Аенська Н. І. Сучасна структура та ефективність методів менеджменту. Ринкова економіка: сучасна теорія і практика управління. 2015. Том 15. Вип. 2 (33). С.105-122.

11. Бліхар М. М. Методи адміністративно-правового регулювання інвестиційної діяльності в Україні. 2014. С. 16-21.

12. Виноградський М. Д., Виноградська А. М., Шканова О. М. Управління персоналом. 2-ге видання: Навч. посіб. К.: Центр учбової літератури, 2009. 502 с. URL: https://pidruchniki.com/1640022150772/ menedzhment/trudova_distsiplina _ distsiplinarniy_vpliv

13. Управління дисципліною: дисциплінарні заохочення та стягнення. Освіта. иа. Менеджмент.2011. URL http://ru.osvita.ua/ vnz/reports/management/15270/

14. Малиновський В.Я. Державне управління: Навчальний посібник. -Луцьк: Ред.-вид. відд. «Вежа « Вол. держ. ун-ту ім. Аесі Українки, 2000.558 с.

\section{SUMMARY}

The article, based on the analysis of norms of the current legislation and scientific views of scientists, defines and characterizes the administrative forms and methods of exercising departmental control over the activity of courts (judges) in Ukraine. It is stated that the definition and research of administrative forms and methods of exercising departmental control over the activity of courts (judges) in Ukraine is of great theoretical and practical importance, as these scientific categories most fully and comprehensively reflect the nature and purpose of such control activities.

Administrative-legal forms of exercising departmental control over the activity of courts (judges) in Ukraine means the external expression of the practical activity of authorized entities, which is connected with the exercise of their supervisory powers, and aimed at achieving the ultimate goal, which is to ensure the quality, effective and legal judiciary in our country. The following forms include: direct examination of the activities of judges, the varieties of which are: inspection, review, audit, inventory; as well as familiarization with the statistical reporting coming from the controlled entity.

Administrative-legal methods of exercising control over the activity of courts (judges) in Ukraine are proposed to be understood as a set of statutory instruments and techniques used by authorized entities in their activities of control in the field of public relations. The following methods include: persuasion method; regulatory method; method of disciplinary training; planning method; method of regulation.

Keywords: administrative method, administrative form, departmental control.

15. Управління людськими ресурсами: філософські засади. Навчальний посібник під ред. д. Ф. н., проф. В. Г. Воронкової. К.: ВД «Професіонал», 2006. 576с

16. Теория государства и права: курс лекций; под ред. Н. И. Матузова, А. В. Малько. 2-е изд., перереб. и доп. М.: Юристь, 2004. 726 c. 